\title{
Glufosinate Effects on Nitrogen Nutrition, Growth, Yield, and Seed Composition in Glufosinate-Resistant and Glufosinate-Sensitive Soybean
}

\author{
Krishna N. Reddy, ${ }^{1}$ Robert M. Zablotowicz, ${ }^{1}$ Nacer Bellaloui, ${ }^{2}$ and Wei Ding ${ }^{1,3}$ \\ ${ }^{1}$ Crop Production Systems Research Unit, USDA-Agricultural Research Service, 141 Experiment Station Road, Stoneville, \\ MS 38776, USA \\ ${ }^{2}$ Crop Genetics Research Unit, USDA-Agricultural Research Service, 141 Experiment Station Road, Stoneville, MS 38776, USA \\ ${ }^{3}$ Department of Plant Protection and Key Laboratory of Soybean Biology in Chinese Ministry of Education, Agronomy College, \\ Northeast Agricultural University, Harbin, Heilongjiang 150030, China \\ Correspondence should be addressed to Krishna N. Reddy, krishna.reddy@ars.usda.gov
}

Received 7 April 2011; Accepted 6 June 2011

Academic Editor: Patrick J. Tranel

Copyright ( $\odot 2011$ Krishna N. Reddy et al. This is an open access article distributed under the Creative Commons Attribution License, which permits unrestricted use, distribution, and reproduction in any medium, provided the original work is properly cited.

Glufosinate applied to glufosinate-resistant crops may drift and injure glufosinate-sensitive crops. A 2-yr field study examined glufosinate effects on plant injury, chlorophyll content, nodulation, nitrogenase activity, leaf nitrogen, yield, and seed composition in soybean. Glufosinate drift was simulated by application at $45 \mathrm{~g} / \mathrm{ha}$ to glyphosate-resistant and conventional (glufosinatesensitive) soybean at 3 weeks after planting (WAP). Glufosinate effects were also evaluated in glufosinate-resistant soybean at $450 \mathrm{~g} / \mathrm{ha}$ applied twice at 3 and 6 WAP. In glufosinate-resistant soybean, chlorophyll, nitrogenase activity, root respiration, plant biomass, and yield were not affected; seed nitrogen and protein were increased; seed oil content decreased. In glufosinate-sensitive soybean, glufosinate caused $28-32 \%$ injury and decreased $35-42 \%$ chlorophyll content within $3 \mathrm{~d}$ after treatment (DAT) but soybean completely recovered by 14 DAT. Glufosinate had no effect on plant biomass, nitrogenase activity, and root respiration in 2009 and inconsistent effects in 2010. In glufosinate-sensitive soybean, glufosinate had no effect on yield; increased leaf nitrogen, seed protein, and oleic acid; decreased oil content, linoleic, and linolenic acid. Glufosinate-sensitive soybean exposed to glufosinate drift may exhibit transient injury but soybean could recover without a yield penalty. Glufosinate altered seed composition in all soybean types.

\section{Introduction}

Glufosinate[2-amino-4-(hydroxymethylphosphinyl)butanoicacid] is a nonselective, postemergence herbicide that controls a broad spectrum of annual and perennial grass and broadleaf weeds in crop and noncrop lands [1-4]. Glufosinate transport in xylem or phloem is limited $[1,5,6]$ thus thorough spray coverage is required for complete kill of targeted weeds. As glufosinate cannot move to underground rhizomes and stolons, the control of perennial weeds is limited. Glufosinate inhibits glutamine synthetase, the enzyme that converts glutamate and ammonia to glutamine [7]. Following glufosinate application, ammonia levels in plants increase dramatically, resulting in metabolic disruption and plant death. Glufosinate disrupts many important nitrogen metabolism (nitrogen assimilation) reactions in plants by inhibiting glutamine synthesis and indirectly inhibiting electron flow in photosynthesis. Ammonia reduces the $\mathrm{pH}$ gradient across the membrane which uncouples photophosphorylation $[1,7,8]$. Injury symptoms such as chlorosis and wilting usually occur within $3-5 \mathrm{~d}$ after glufosinate application, followed by necrosis in 1-2 weeks.

Several crops have been made resistant to glufosinate by stable integration of a transgene that encodes a phosphinothricin acetyltransferase. Phosphinothricin acetyltransferase converts glufosinate to a nonherbicidal acetylated 
form in plants [1]. Glufosinate-resistant canola was commercialized in 1995 followed by glufosinate-resistant corn in 1996, glufosinate-resistant cotton in 2004, and glufosinateresistant soybean in 2009 [9]. Consequently, glufosinate application frequency has increased with the adoption of these glufosinate-resistant crops and the application window has widened because of differences in planting dates among these crops. Glufosinate drift is a concern because the compound is nonselective and could cause injury to nontarget sensitive crops. In 2010, about $7 \%$ of soybean area was planted with conventional (glufosinate and glyphosate sensitive) cultivars [10]. Furthermore, due to their remarkable success, glyphosate-resistant crops have dominated the US seed market, the area planted to glufosinate-resistant crops is negligible. Currently, there are no reports of any weed species resistance to glufosinate, while 20 have already developed resistance to glyphosate worldwide [11]. Glufosinate-resistant soybean cultivars provide a needed tool to manage glyphosate-resistant weeds [12], and the area planted to glufosinate-resistant cultivars will likely increase. Thus, the potential for glufosinate drift on to nontarget glyphosate-resistant and conventional (glufosinate-sensitive) soybean does exist. Nonlethal physiological and metabolic disturbances due to glufosinate exposure have been observed in glufosinate-sensitive soybean. Glufosinate application at 26 and $53 \mathrm{~g} / \mathrm{ha}$ reduced plant height by 11 to $21 \%$ and caused 39 to $40 \%$ injury in soybean and cotton [13]. However, both crops recovered rapidly and glufosinate exposure did not affect yields. In another study, glufosinate application at $53 \mathrm{~g} / \mathrm{ha}$ reduced yields up to 3 to $30 \%$ in rice and 11 to $13 \%$ in corn [14].

Glufosinate could disrupt many important nitrogen metabolism (nitrogen assimilation) reactions in plants by inhibiting glutamine formation. Glutamine synthetase seems to be involved in the control of rhizobium nitrogenase [15] thus the implications of inhibition of nitrogen fixation by glufosinate merits investigation. Information on the effects of glufosinate on nitrogen fixation, yield, and seed composition in glufosinate-resistant, glyphosate-resistant, and conventional soybean is limited. The objectives of this study were to determine the effects of glufosinate at label rate on nitrogen fixation, leaf nitrogen, yield, and seed composition in glufosinate-resistant trait soybean and to determine the effects of drift rate of glufosinate on plant injury, nitrogen fixation, leaf nitrogen, yield, and seed composition in glyphosate-resistant and conventional soybean.

\section{Materials and Methods}

\subsection{Field Experimental Conditions}

A 2-yr field study was conducted during 2009 and 2010 at the USDA-ARS Crop Production Systems Research farm, Stoneville, MS, under an irrigated environment. The soil was a Dundee silt loam (fine-silty, mixed, active, thermic Typic Endoqualf) with pH 6.7, 1.1\% organic matter, a cation exchange capacity of $15 \mathrm{cmol} / \mathrm{kg}$, and soil textural fractions of $26 \%$ sand, $55 \%$ silt, and $19 \%$ clay. The experimental area was under glyphosate-resistant soybean production for two years prior to this study. Seedbed preparation consisted of disking, subsoiling, disking, and bedding in the fall of the previous year. Prior to planting, the raised beds were smoothed as needed. Soybean was planted in $102-\mathrm{cm}$ wide rows using a MaxEmerge 2 planter (Deere and Co., Moline, IL) at 350,000 seeds/ha on May 18, 2009 and April 28, 2010. $S$-metolachlor at $1.12 \mathrm{~kg}$ ai $/$ ha plus pendimethalin at $1.12 \mathrm{~kg}$ ai/ha plus paraquat at $1.12 \mathrm{~kg}$ ai/ha were applied to the entire experimental area immediately after planting. Paraquat was applied to kill existing weeds at planting, s-metolachlor and pendimethalin were used to provide early-season weed control. Herbicides were applied with a tractor-mounted sprayer with TeeJet 8004 standard flat spray nozzles (Tee)et Spraying Systems Co., Wheaton, IL), delivering $187 \mathrm{~L} / \mathrm{ha}$ water at $179 \mathrm{kPa}$. All plots including glufosinate treated were hand weeded periodically throughout the season to keep weed-free. No fertilizer nitrogen was applied and the crop was irrigated on an as-needed basis each year. The experiment was conducted in a randomized complete block design with six replications. Each treatment plot consisted of four rows spaced $102-\mathrm{cm}$ apart and $15.2 \mathrm{~m}$ long.

2.1.1. Glufosinate-Resistant Soybean. Glufosinate-resistant soybean cultivars "S080120LL" in 2009 and "SG4989NLL" in 2010 were planted to assess nitrogen nutrition, growth, yield, and seed composition responses to label rates of glufosinate. Cultivar "SG4989NLL" was used in 2010 for lack of availability of "S080120LL". Glufosinate was applied twice at 3 (early postemergence, EPOST) and 6 (late postemergence, LPOST) wk after planting (WAP) at a rate of $450 \mathrm{~g}$ ai/ha. A $450 \mathrm{~g}$ ai/ha represents the suggested label-use rate (1x). At 3 WAP, soybean was at the two-to- three-trifoliolate leaf (V3-V4) stage and 6 WAP, soybean was at the six-to- seventrifoliolate leaf (V7-V8) stage.

2.1.2. Conventional and Glyphosate-Resistant Soybean. A conventional soybean cultivar "Williams 82" and glyphosateresistant soybean cultivar "AG4605RR/S" were planted in separate experiments to assess physiological and yield responses to simulated glufosinate drift. A single application of glufosinate at $45 \mathrm{~g}$ ai/ha was applied at 3 WAP (EPOST), when plants were at the two-to- three-trifoliolate leaf stage. Glufosinate rate of $45 \mathrm{~g} / \mathrm{ha}$ was selected to represent $10 \%$ of the suggested label use rate $(450 \mathrm{~g} / \mathrm{ha})$ to simulate herbicide drift. Other researchers have used 1 to $20 \%$ of recommended rate in herbicide simulated drift studies with various crops $[13,14,16,17]$.

2.2. Shoot, Root and Nodule Biomass, Acetylene Reduction Assay, and Root Respiration. Ten soybean plants were randomly sampled from the middle two rows of each plot at 3 and $12 \mathrm{~d}$ after first glufosinate application in all three soybean types and 3 and $12 \mathrm{~d}$ after the second glufosinate application in glufosinate-resistant soybean. Plants were excavated with roots and shoots intact, immediately transported to the laboratory, and assayed within $30 \mathrm{~min}$. Nitrogenase activity 
was assayed using the acetylene reduction assay as described elsewhere $[16,18]$. Briefly, roots with nodules intact were excised and incubated in $1 \mathrm{~L}$ Mason jars. Six roots were placed in the jars and sealed, and a 10\% volume of air was removed and replaced with an equal volume of acetylene. After one hour incubation at room temperature, duplicate $1 \mathrm{~mL}$ gas samples were removed and analyzed by gas chromatography for ethylene formation and $\mathrm{CO}_{2}$ evolution as described previously $[18,19]$. An Agilent HP6960 (Agilent Technologies, Wilmington, DE) gas chromatograph equipped with flame ionization detector (FID), and thermal conductivity detector (TCD) was used for quantification of ethylene formation and $\mathrm{CO}_{2}$ accumulation, respectively. Following the incubation, roots were washed, and the nodules were removed from the roots. The nodules, roots, and shoots were oven-dried at $\left(60^{\circ} \mathrm{C}, 72 \mathrm{~h}\right)$ and their dry weights were recorded.

2.3. Leaf Nitrogen, Seed Nitrogen, and Delta ${ }^{15} \mathrm{~N}$. About 25 youngest fully expanded trifoliolate leaves from the middle two rows of each plot were randomly sampled at V5 and R4 [20] soybean growth stages each year. At harvest about 200 soybean pods were randomly sampled from the middle two rows for seed nitrogen content. Leaf and grain samples were oven-dried $\left(60^{\circ} \mathrm{C}, 96 \mathrm{~h}\right)$ and finely ground. Samples were redried the night before nitrogen analysis to remove any moisture that may have been absorbed. Total nitrogen was determined from duplicate samples (10-15 mg) using a Flash EA 112 elemental analyzer (CE Elantech, Lakewood, $\mathrm{NJ}$ ). Nitrogen was expressed as percent of leaf and seed dry weight.

To evaluate if $\mathrm{N}_{2}$ fixation was affected, nitrogen isotopic discrimination mass spectroscopy was utilized to characterize the delta ${ }^{15} \mathrm{~N}$ abundance based on nitrogen isotope ${ }^{15} \mathrm{~N} /{ }^{14} \mathrm{~N}$ ratio [21] in leaf samples taken at $\mathrm{R} 4$ soybean growth stage. Analysis was conducted by the University of California Berkeley Center for Stable Isotope Biogeochemistry using a Finnigan MAT Delta plus XL mass spectrophotometer (Brennan, Germany) interfaced with a CE Elantech 1500 elemental analyzer as a combustion system. The instrument was calibrated using National Institute of Standards and Technology standards. Duplicate $5 \mathrm{mg}$ leaf samples were analyzed for each plot.

2.4. Chlorophyll Determination. Chlorophyll content was determined at 3 and $12 \mathrm{~d}$ after first glufosinate application in all three soybean types and $3 \mathrm{~d}$ after second glufosinate application in glufosinate-resistant soybean type only using the youngest fully expanded leaf from three plants in each pot. Chlorophyll was extracted with $10 \mathrm{~mL}$ dimethyl sulfoxide and chlorophyll concentrations were quantified spectrophotometrically as described by Hiscox and Israelstam [22]. Total chlorophyll content was expressed as $\mathrm{mg} / \mathrm{g}$ leaf fresh weight.

2.5. Soybean Injury and Yield. Soybean injury was visually estimated on a scale of 0 (no injury) to $100 \%$ (death). Injury was estimated at 3 and $12 \mathrm{~d}$ after first glufosinate application.
Soybean from all four rows in each plot were harvested using a combine, and grain yield was adjusted to $13 \%$ moisture.

2.6. Seed Protein, Oil, and Fatty Acids. Soybean grain from each treatment was analyzed for protein, oil, and fatty acids percentages using near-infrared reflectance diode array feed analyzer (Perten, Springfield, IL). The calibration equation was developed by the University of Minnesota using Perten's Thermo Galactic Grams PLS IQ software (Springfield, IL). The calibration curve has been regularly updated according to Association of Official Analytical Chemists [23, 24] methods. The analysis was performed on the basis of percent dry matter $[25,26]$.

2.7. Greenhouse Experiments. Greenhouse experiments were conducted during spring 2010 at the USDA-ARS Crop Production Systems Research Unit, Stoneville, MS. A glufosinate-resistant soybean cultivar (S080120LL), glyphosate-resistant cultivar (AG4605RR/S), and a conventional cultivar (Williams 82) were grown in 15-cm diameter plastic pots containing $1.7 \mathrm{~kg}$ of $1: 1(\mathrm{v} / \mathrm{v})$ mixture of Bosket sandy loam soil (fine-loamy, mixed, and thermic Mollic Hapludalfs) and Dundee silty clay loam soil (fine-silty, mixed, and thermic Aeric Ochraqualf). The Dundee silty clay loam was from a field under continuous soybean production for four years and contained an abundant native population of Bradyrhizobium japonicum. The greenhouse was maintained at $28 / 22 \pm 3^{\circ} \mathrm{C}$, day/night, temperature with natural light supplemented by sodium vapor lamps to provide a 13-h photoperiod. Soybeans were seeded and later thinned to three uniform plants per pot after emergence and subirrigated with distilled water as needed. Soybean plants at the two-trifoliolate leaf ( $21 \mathrm{~d}$ from sowing) stage were used for glufosinate treatment. Glufosinate was applied at a rate of 450 and $1,350 \mathrm{~g} / \mathrm{ha}$ to glufosinate-resistant soybean. Conventional and glyphosate-resistant soybean were treated with 45 and $135 \mathrm{~g} / \mathrm{ha}$ glufosinate to simulate drift of 10 and $30 \%$ of the label recommended rate. The higher rate was selected to represent the "worst case scenario" to promote soybean injury. Spray solutions were prepared using a commercial formulation of glufosinate. Spray solutions were applied using an indoor spray chamber equipped with an air-pressurized system delivering $190 \mathrm{~L} / \mathrm{ha}$ at $140 \mathrm{kPa}$ using $8002 \mathrm{E}$ flat-fan nozzles. Treatments were arranged in a randomized complete block design with seven replications and the experiment was repeated.

Nitrogenase activity, root respiration, shoot, root and nodule biomass, and shoot nitrogen content were determined as described above. All three plants in each pot were sampled at $12 \mathrm{~d}$ after glufosinate application in all three soybean types. Three roots with nodules intact were incubated in $60 \mathrm{~mL}$ plastic syringes instead of $1 \mathrm{~L}$ Mason jars sealed with rubber septums.

2.8. Statistical Analysis. Data from each soybean type were analyzed separately to study the effects of glufosinate within each soybean type. Data were subjected to analysis of variance using PROC MIXED (Statistical Analysis Systems, 
TABLe 1: Glufosinate effect on plant injury, chlorophyll content, and yield in glufosinate-resistant, glyphosate-resistant, and conventional soybean in a field study at Stoneville, MS, 2009 and $2010^{\mathrm{a}}$.

\begin{tabular}{|c|c|c|c|c|c|c|}
\hline \multirow{2}{*}{ Herbicide } & \multirow{2}{*}{ Rate $(g / h a)$} & \multirow{2}{*}{ Application timing } & \multirow{2}{*}{$\begin{array}{c}\text { Plant injury }(\%) \\
3 \text { d EPOST }\end{array}$} & \multicolumn{2}{|c|}{ Chlorophyll (mg/g leaf) } & \multirow{2}{*}{$\begin{array}{c}\text { Soybean } \\
\text { yield }(\mathrm{kg} / \mathrm{ha})\end{array}$} \\
\hline & & & & $3 \mathrm{~d}$ EPOST & $14 \mathrm{~d}$ EPOST & \\
\hline \multicolumn{7}{|c|}{ Glufosinate-resistant soybean } \\
\hline No glufosinate & 0 & & $0^{\mathrm{a}}$ & $1.63^{\mathrm{a}}$ & $1.74^{\mathrm{a}}$ & $3749^{a}$ \\
\hline Glufosinate $\mathrm{fb}$ & 450 & EPOST & $3^{\mathrm{a}}$ & $1.50^{\mathrm{a}}$ & $1.86^{\mathrm{a}}$ & $3812^{\mathrm{a}}$ \\
\hline glufosinate & 450 & LPOST & & & & \\
\hline \multicolumn{7}{|c|}{ Glyphosate-resistant soybean } \\
\hline No glufosinate & 0 & & $0^{\mathrm{b}}$ & $1.43^{\mathrm{a}}$ & $1.69^{\mathrm{a}}$ & $4911^{\mathrm{a}}$ \\
\hline Glufosinate & 45 & EPOST & $28^{\mathrm{a}}$ & $0.93^{\mathrm{b}}$ & $1.56^{\mathrm{a}}$ & $4910^{\mathrm{a}}$ \\
\hline \multicolumn{7}{|c|}{ Conventional soybean } \\
\hline No glufosinate & 0 & & $0^{\mathrm{b}}$ & $1.58^{\mathrm{a}}$ & $1.56^{\mathrm{a}}$ & $3394^{\mathrm{a}}$ \\
\hline Glufosinate & 45 & EPOST & $32^{\mathrm{a}}$ & $0.92^{\mathrm{b}}$ & $1.57^{\mathrm{a}}$ & $3379^{a}$ \\
\hline
\end{tabular}

Abbreviations: fb: followed by; EPOST: early postemergence applied at $3 \mathrm{wk}$ after planting; LPOST: late postemergence applied at $6 \mathrm{wk}$ after planting.

${ }^{a}$ Means within a column for each soybean type followed by the same letter are not statistically significant at the $5 \%$ level as determined by Fisher's LSD test.

TABLE 2: Glufosinate effect on shoot, root, and nodule biomass, nitrogenase activity, and root respiration in glufosinate-resistant soybean under field conditions in 2009 and 2010. Data represent the mean of 3 and $12 \mathrm{~d}$ after early postemergence application in 2009 and 2010.

\begin{tabular}{|c|c|c|c|c|c|c|}
\hline \multirow{2}{*}{$\begin{array}{l}\text { Application } \\
\text { timing }\end{array}$} & \multirow{2}{*}{$\begin{array}{l}\text { Glufosinate } \\
\text { rate (g/ha) }\end{array}$} & \multicolumn{3}{|c|}{ Dry biomass (mg/plant) } & \multirow{2}{*}{$\begin{array}{c}\text { Nitrogenase activity } \\
(\mu \mathrm{mol} \text { ethylene formed/ } \\
\text { plant } / \mathrm{h})\end{array}$} & \multirow{2}{*}{$\begin{array}{c}\text { Root respiration } \\
(\mu \mathrm{mol} \mathrm{CO} 2 / \text { plant } / \mathrm{h})\end{array}$} \\
\hline & & Nodule & Shoot & Root & & \\
\hline \multirow[t]{3}{*}{ EPOST } & 0 & 45 & 2133 & 445 & 6.6 & 62.6 \\
\hline & 450 & 44 & 2106 & 441 & 6.7 & 64.9 \\
\hline & $P$ & 0.98 & 0.87 & 0.87 & 0.59 & 0.14 \\
\hline \multirow[t]{3}{*}{ LPOST } & 0 & 77 & 3435 & 559 & 9.6 & 75.7 \\
\hline & 450 & 77 & 3260 & 508 & 10.5 & 74.8 \\
\hline & $P$ & 0.98 & 0.35 & 0.23 & 0.59 & 0.78 \\
\hline
\end{tabular}

Abbreviations: fb: followed by; EPOST: early postemergence applied at $3 \mathrm{wk}$ after planting; LPOST: late postemergence applied at $6 \mathrm{wk}$ after planting.

Statistical Analysis Systems Institute, Cary, NC), and treatment means were separated at the $5 \%$ level of significance using Fisher's protected LSD test. Data were averaged across two years (field experiments) and two trials (greenhouse experiments) as year/trial by glufosinate treatment interactions were not significant.

\section{Results and Discussion}

\subsection{Field Experiment}

3.1.1. Soybean Injury and Chlorophyll Content. Visible injury symptoms such as chlorosis and necrosis of leaves that intercepted spray were apparent within $3 \mathrm{~d}$ after glufosinate application in glyphosate-resistant and conventional soybean. Glufosinate applied at drift rate caused 28 to $32 \%$ injury in glyphosate-resistant and conventional soybean at 3 d EPOST (Table 1). Soybean injury decreased overtime, and soybean completely recovered from injury within $14 \mathrm{~d}$ after application (data not shown). These findings are similar to those reported previously in the literature [13]. Glufosinate applied at drift rates (4 to $53 \mathrm{~g} / \mathrm{ha}$ ) to 2- to 3trifoliloate leaf stage soybean caused 0 to $40 \%$ injury at 7
DAT, injury decreased to 0 to $14 \%$ by 14 DAT, and soybean completely recovered by 28 DAT [13]. Glufosinate applied sequentially at label rate did not cause injury $(\leq 3 \%)$ in glufosinate-resistant soybean as was expected (Table 1).

Glufosinate applied at drift rate reduced chlorophyll content of leaves by 35 to $42 \%$ in glyphosate-resistant and conventional soybean at $3 \mathrm{~d}$ EPOST and chlorophyll content recovered to levels similar to those in nontreated plants by $14 \mathrm{~d}$ EPOST (Table 1). Chlorophyll content at either 3 or $14 \mathrm{~d}$ EPOST in glufosinate-resistant soybean was not affected by sequential label rate applications (Table 1).

3.1.2. Plant Shoot and Root Biomass, Nodule Biomass, Acetylene Reduction Assay, and Root Respiration. In glufosinateresistant soybean, glufosinate applied sequentially at label rate (450 and $450 \mathrm{~g} / \mathrm{ha}$ ) had no deleterious effect on plant root and shoot biomass, nodule biomass, nitrogenase activity, or root respiration at 3 and $12 \mathrm{~d}$ after application in both years (Table 2).

Glyphosate-resistant soybean was more sensitive to glufosinate at a drift rate of $45 \mathrm{~g} / \mathrm{ha}$ in 2010 than in 2009 . This may be due in part to differences in weather. Weather during 12 days following treatment in 2009 was hot and 
TABLE 3: Glufosinate effect on shoot, root, and nodule biomass, nitrogenase activity, and root respiration in glyphosate-resistant soybean under field conditions in 2009 and 2010.

\begin{tabular}{|c|c|c|c|c|c|c|c|}
\hline \multirow{2}{*}{ Year } & \multirow{2}{*}{$\begin{array}{l}\text { Sampling } \\
\text { time }\end{array}$} & \multirow{2}{*}{$\begin{array}{l}\text { Glufosinate } \\
\text { rate }(\mathrm{g} / \mathrm{ha})\end{array}$} & \multicolumn{3}{|c|}{ Dry biomass (mg/plant) } & \multirow{2}{*}{$\begin{array}{l}\text { Nitrogenase activity ( } \mu \mathrm{mol} \\
\text { ethylene formed/plant/h) }\end{array}$} & \multirow{2}{*}{$\begin{array}{c}\text { Root respiration } \\
\left(\mu \mathrm{mol} \mathrm{CO} \mathrm{CO}_{2} / \text { plant } / \mathrm{h}\right)\end{array}$} \\
\hline & & & Nodule & Shoot & Root & & \\
\hline \multirow[t]{6}{*}{2009} & 3 DAT & 0 & 30 & 1472 & 381 & 2.16 & 26.8 \\
\hline & & 45 & 46 & 1355 & 358 & 2.98 & 28.8 \\
\hline & & $P$ & 0.22 & 0.24 & 0.31 & 0.63 & 0.39 \\
\hline & 12 DAT & 0 & 66 & 3575 & 748 & 5.40 & 53.0 \\
\hline & & 45 & 50 & 3841 & 661 & 4.00 & 46.7 \\
\hline & & $P$ & 0.15 & 0.41 & 0.23 & 0.05 & 0.16 \\
\hline \multirow[t]{6}{*}{2010} & $3 \mathrm{DAT}$ & 0 & 52 & 2060 & 303 & 3.66 & 38.3 \\
\hline & & 45 & 34 & 1366 & 271 & 2.10 & 26.3 \\
\hline & & $P$ & 0.008 & 0.01 & 0.26 & 0.004 & 0.01 \\
\hline & $12 \mathrm{DAT}$ & 0 & 73 & 3885 & 520 & 19.30 & 156.6 \\
\hline & & 45 & 61 & 2570 & 393 & 20.80 & 146.5 \\
\hline & & $P$ & 0.08 & 0.02 & 0.005 & 0.68 & 0.36 \\
\hline
\end{tabular}

Abbreviations: DAT: days after early postemergence application.

TABLE 4: Glufosinate effect on shoot, root, and nodule biomass, nitrogenase activity, and root respiration in conventional (glufosinate and glyphosate sensitive) soybean under field conditions in 2009 and 2010.

\begin{tabular}{|c|c|c|c|c|c|c|c|}
\hline \multirow{2}{*}{ Year } & \multirow{2}{*}{$\begin{array}{l}\text { Sampling } \\
\text { time }\end{array}$} & \multirow{2}{*}{$\begin{array}{l}\text { Glufosinate } \\
\text { rate }(g / h a)\end{array}$} & \multicolumn{3}{|c|}{ Dry biomass (mg/plant) } & \multirow{2}{*}{$\begin{array}{l}\text { Nitrogenase activity }(\mu \mathrm{mol} \\
\text { ethylene formed/plant/h) }\end{array}$} & \multirow{2}{*}{$\begin{array}{c}\text { Root respiration } \\
\left(\mu \mathrm{mol} \mathrm{CO} \mathrm{CO}_{2} / \text { plant } / \mathrm{h}\right)\end{array}$} \\
\hline & & & Nodule & Shoot & Root & & \\
\hline \multirow[t]{6}{*}{2009} & $3 \mathrm{DAT}$ & 0 & 73 & 1248 & 315 & 3.5 & 29.4 \\
\hline & & 45 & 49 & 1200 & 273 & 3.7 & 31.0 \\
\hline & & $P$ & 0.22 & 0.82 & 0.31 & 0.63 & 0.39 \\
\hline & 12 DAT & 0 & 81 & 3261 & 638 & 7.1 & 49.5 \\
\hline & & 45 & 77 & 3475 & 656 & 6.5 & 54.1 \\
\hline & & $P$ & 0.68 & 0.42 & 0.62 & 0.50 & 0.32 \\
\hline \multirow[t]{6}{*}{2010} & 3 DAT & 0 & 42 & 2110 & 295 & 3.9 & 35.9 \\
\hline & & 45 & 36 & 1717 & 236 & 7.8 & 27.7 \\
\hline & & $P$ & 0.28 & 0.09 & 0.14 & 0.06 & 0.007 \\
\hline & 12 DAT & 0 & 40 & 3942 & 613 & 35.5 & 263.5 \\
\hline & & 45 & 35 & 2956 & 531 & 30.4 & 215.6 \\
\hline & & $P$ & 0.18 & 0.02 & 0.24 & 0.03 & 0.001 \\
\hline
\end{tabular}

Abbreviations: DAT: days after early postemergence application.

dry $\left(34.7^{\circ} \mathrm{C}\right.$ maximum daily air temperature and no rainfall $)$ compared to $2010\left(32.8^{\circ} \mathrm{C}\right.$ maximum daily air temperature and $2.9 \mathrm{~cm}$ rainfall). Soybean was actively growing in 2010 compared to soybean under stress in 2009. Shoot, root, and nodule biomass was significantly reduced in glufosinatetreated soybean at 3 and 12 DAT sampling dates in 2010 but not in 2009 (Table 3). Nitrogenase activity was significantly reduced at 12 DAT in 2009 and 3 DAT in 2010. However, in conventional soybean, shoot biomass was reduced by a drift rate of glufosinate only in 2010 (Table 4). Nitrogenase activity and root respiration were unaffected in 2009 and were reduced in 2010 .

3.1.3. Leaf Nitrogen, Seed Nitrogen, and Delta ${ }^{15} N$. In glufosinate-resistant soybean, glufosinate significantly increased foliar nitrogen content at the V5 growth stage
(Table 5), but had no effect at V7, V9 (data not shown), or at the R4 stage of development (Table 5). Seed nitrogen content was higher in glufosinate-treated than in nontreated glufosinate-resistant soybean. Although there were indications of increased nitrogen in plant tissue in glufosinatetreated compared to nontreated soybean, the delta ${ }^{15} \mathrm{~N}$ values were similar and relatively low for treated and nontreated soybean indicating that nitrogen fixation through the midreproductive stage of development supplied most of the leaf nitrogen and nitrogen fixation was not influenced by glufosinate application.

In glyphosate-resistant soybean, glufosinate had no effect on foliar nitrogen content at V5 growth stage, but increased foliar nitrogen at R4 stage of development (Table 5). In contrast to the glufosinate-resistant soybean, seed nitrogen 
TABLE 5: Effect of glufosinate application on leaf and seed nitrogen content and delta ${ }^{15} \mathrm{~N}$ in glufosinate-resistant, glyphosate-resistant, and conventional soybean in a field study at Stoneville, MS, 2009 and $2010^{\mathrm{a}}$.

\begin{tabular}{|c|c|c|c|c|c|c|}
\hline \multirow{2}{*}{ Herbicide } & \multirow{2}{*}{ Rate (g/ha) } & \multirow{2}{*}{ Application timing } & \multicolumn{3}{|c|}{ Nitrogen content (\%) } & \multirow{2}{*}{ Delta ${ }^{15} \mathrm{~N}^{\mathrm{b}}$} \\
\hline & & & Leaf at V5 & Leaf at R4 & Seed & \\
\hline \multicolumn{7}{|c|}{ Glufosinate-resistant soybean } \\
\hline No glufosinate & 0 & & $4.84^{\mathrm{b}}$ & $5.64^{\mathrm{a}}$ & $6.22^{\mathrm{b}}$ & $0.20^{\mathrm{a}}$ \\
\hline Glufosinate $\mathrm{fb}$ & 450 & EPOST & $5.23^{\mathrm{a}}$ & $5.87^{\mathrm{a}}$ & $6.38^{\mathrm{a}}$ & $0.21^{\mathrm{a}}$ \\
\hline glufosinate & 450 & LPOST & & & & \\
\hline \multicolumn{7}{|c|}{ Glyphosate-resistant soybean } \\
\hline No glufosinate & 0 & & $5.17^{\mathrm{a}}$ & $5.85^{\mathrm{b}}$ & $6.49^{\mathrm{a}}$ & $0.83^{\mathrm{a}}$ \\
\hline Glufosinate & 45 & EPOST & $5.13^{\mathrm{a}}$ & $6.05^{\mathrm{a}}$ & $6.64^{\mathrm{a}}$ & $0.76^{\mathrm{a}}$ \\
\hline \multicolumn{7}{|c|}{ Conventional soybean } \\
\hline No glufosinate & 0 & & $5.31^{\mathrm{b}}$ & $5.06^{\mathrm{b}}$ & $6.30^{\mathrm{a}}$ & $0.55^{\mathrm{a}}$ \\
\hline Glufosinate & 45 & EPOST & $5.78^{\mathrm{a}}$ & $5.39^{\mathrm{a}}$ & $6.25^{\mathrm{a}}$ & $0.69^{a}$ \\
\hline
\end{tabular}

Abbreviations: fb: followed by; EPOST: early postemergence applied at $3 \mathrm{wk}$ after planting; LPOST: late postemergence applied at $6 \mathrm{wk}$ after planting. ${ }^{a}$ Means within a column for each soybean type followed by the same letter are not statistically significant at the 5\% level as determined by Fisher's LSD test.

${ }^{\mathrm{b}}$ Delta ${ }^{15} \mathrm{~N}$ was determined in leaf samples taken at $\mathrm{R} 4$ soybean growth stage.

TABLE 6: Effect of glufosinate application on seed composition in glufosinate-resistant, glyphosate-resistant, and conventional soybean in a field study at Stoneville, MS, 2009 and $2010^{a}$.

\begin{tabular}{|c|c|c|c|c|c|c|c|}
\hline \multirow{2}{*}{ Herbicide } & \multirow{2}{*}{ Rate (g/ha) } & \multirow{2}{*}{ Application timing } & \multicolumn{5}{|c|}{ Soybean seed } \\
\hline & & & $\begin{array}{l}\text { Protein } \\
(\mathrm{g} / \mathrm{kg})\end{array}$ & $\begin{array}{c}\text { Oil } \\
(\mathrm{g} / \mathrm{kg})\end{array}$ & $\begin{array}{l}\text { Oleic acid } \\
(\%)\end{array}$ & $\begin{array}{c}\text { Linoleic acid } \\
(\%)\end{array}$ & $\begin{array}{c}\text { Linolenic acid } \\
(\%)\end{array}$ \\
\hline \multicolumn{8}{|c|}{ Glufosinate-resistant soybean } \\
\hline No glufosinate & 0 & & $416^{\mathrm{b}}$ & $209^{\mathrm{a}}$ & $22.6^{\mathrm{b}}$ & $54.4^{\mathrm{a}}$ & $8.4^{\mathrm{a}}$ \\
\hline Glufosinate $\mathrm{fb}$ & 450 & EPOST & $427^{\mathrm{a}}$ & $200^{\mathrm{b}}$ & $26.1^{\mathrm{a}}$ & $54.0^{\mathrm{a}}$ & $7.0^{\mathrm{b}}$ \\
\hline glufosinate & 450 & LPOST & & & & & \\
\hline \multicolumn{8}{|c|}{ Glyphosate-resistant soybean } \\
\hline No glufosinate & 0 & & $406^{\mathrm{b}}$ & $214^{\mathrm{a}}$ & $20.3^{\mathrm{b}}$ & $56.7^{\mathrm{a}}$ & $8.9^{\mathrm{a}}$ \\
\hline Glufosinate & 45 & EPOST & $431^{\mathrm{a}}$ & $204^{\mathrm{b}}$ & $25.7^{\mathrm{a}}$ & $54.8^{\mathrm{b}}$ & $7.2^{\mathrm{b}}$ \\
\hline \multicolumn{8}{|c|}{ Conventional soybean } \\
\hline No glufosinate & 0 & & $414^{\mathrm{b}}$ & $221^{\mathrm{a}}$ & $20.2^{\mathrm{b}}$ & $56.2^{\mathrm{a}}$ & $8.9^{\mathrm{a}}$ \\
\hline Glufosinate & 45 & EPOST & $434^{\mathrm{a}}$ & $212^{\mathrm{b}}$ & $25.6^{\mathrm{a}}$ & $54.3^{\mathrm{b}}$ & $7.7^{\mathrm{b}}$ \\
\hline
\end{tabular}

Abbreviations: fb: followed by; EPOST: early postemergence applied at $3 \mathrm{wk}$ after planting; LPOST: late postemergence applied at $6 \mathrm{wk}$ after planting. ${ }^{a}$ Means within a column for each soybean type followed by the same letter are not statistically significant at the $5 \%$ level as determined by Fisher's LSD test.

content was unaffected by glufosinate in glyphosate-resistant soybean. Delta ${ }^{15} \mathrm{~N}$ values were similar for treated and nontreated soybean, indicating that nitrogen fixation was not affected by glufosinate application. In conventional soybean, glufosinate increased foliar nitrogen content at the V5 and R4 growth stage; however, seed nitrogen was unaffected. A similar level of delta ${ }^{15} \mathrm{~N}$ enrichment was observed in treated and untreated soybean, again indicating that nitrogen fixation was unaffected by glufosinate application.

3.1.4. Soybean Yield and Seed Composition. Glufosinate applied twice at a $1 \mathrm{x}$ rate to glufosinate-resistant soybean and once at $0.1 \mathrm{x}$ rate to glyphosate-resistant soybean and conventional soybean did not affect yield compared with nontreated soybean (Table 1). Lack of a glufosinate effect on yield in glufosinate-resistant soybean was expected.
Absence of a negative effect of glufosinate at drift rate on yield in conventional soybean as observed in this study is in conformity with previous studies. Ellis and Griffin [13] have shown that simulated drift of 4 to $53 \mathrm{~g}$ ai/ha glufosinate (representing 0.8 to $12.5 \%$ of the $420 \mathrm{~g}$ ai/ha use rate) had no significant effect on yield in conventional soybean.

In glufosinate-resistant soybean, glufosinate treatment increased seed protein content and decreased oil content as compared to nontreated control (Table 6). The fatty acid profiles were substantially affected as the abundance of oleic acid increased and abundance of linolenic acid decreased. Whereas, linoleic (Table 6), stearic, and palmitic acid (data not shown) were unaffected. Soybean with high oleic and low linolenic acid content is highly desirable for storability with lower potential for oxidative changes in storage. In glyphosate-resistant soybean, a drift rate of glufosinate increased protein content but decreased oil content, as was 
TABLE 7: Effect of glufosinate on soybean biomass, nodule biomass, nitrogenase activity, root respiration, and shoot nitrogen content, $12 \mathrm{~d}$ after application under greenhouse conditions ${ }^{\mathrm{ab}}$.

\begin{tabular}{|c|c|c|c|c|c|c|}
\hline \multirow{2}{*}{$\begin{array}{l}\text { Soybean type and glufosinate } \\
\text { rate }(\mathrm{g} / \mathrm{ha})\end{array}$} & \multicolumn{3}{|c|}{ Dry biomass (mg/plant) } & \multirow{2}{*}{$\begin{array}{l}\text { Nitrogenase activity }(\mu \mathrm{mol} \\
\text { ethylene formed/plant/h) }\end{array}$} & \multirow{2}{*}{$\begin{array}{l}\text { Root respiration } \\
(\mu \mathrm{mol} \mathrm{CO} 2 / \text { plant } / \mathrm{h})\end{array}$} & \multirow{2}{*}{$\begin{array}{c}\text { Shoot } \\
\text { nitrogen }(\%)\end{array}$} \\
\hline & Nodule & Shoot & Root & & & \\
\hline \multicolumn{7}{|l|}{ Glufosinate-resistant soybean } \\
\hline 0 & $47^{\mathrm{a}}$ & $802^{\mathrm{a}}$ & $308^{\mathrm{a}}$ & $2.33^{\mathrm{a}}$ & $681^{\mathrm{a}}$ & $2.17^{\mathrm{c}}$ \\
\hline 450 & $45^{\mathrm{a}}$ & $781^{\mathrm{a}}$ & $317^{\mathrm{a}}$ & $2.31^{\mathrm{a}}$ & $683^{\mathrm{a}}$ & $2.43^{\mathrm{b}}$ \\
\hline 1350 & $44^{\mathrm{a}}$ & $757^{\mathrm{a}}$ & $305^{\mathrm{a}}$ & $2.41^{\mathrm{a}}$ & $672^{\mathrm{a}}$ & $2.73^{\mathrm{a}}$ \\
\hline \multicolumn{7}{|l|}{ Glyphosate-resistant soybean } \\
\hline 0 & $46^{\mathrm{a}}$ & $927^{\mathrm{a}}$ & $377^{\mathrm{a}}$ & $1.01^{\mathrm{a}}$ & $263^{\mathrm{a}}$ & $2.48^{\mathrm{c}}$ \\
\hline 45 & $52^{\mathrm{a}}$ & $890^{\mathrm{a}}$ & $381^{\mathrm{a}}$ & $0.86^{\mathrm{a}}$ & $274^{\mathrm{a}}$ & $2.81^{\mathrm{b}}$ \\
\hline 135 & $38^{\mathrm{b}}$ & $636^{\mathrm{b}}$ & $284^{\mathrm{b}}$ & $0.64^{\mathrm{b}}$ & $223^{\mathrm{b}}$ & $3.23^{\mathrm{a}}$ \\
\hline \multicolumn{7}{|l|}{ Conventional soybean } \\
\hline 0 & $48^{\mathrm{a}}$ & $930^{\mathrm{a}}$ & $321^{\mathrm{a}}$ & $1.33^{\mathrm{a}}$ & $251^{\mathrm{a}}$ & $2.35^{\mathrm{c}}$ \\
\hline 45 & $46^{\mathrm{a}}$ & $848^{\mathrm{a}}$ & $325^{\mathrm{a}}$ & $1.13^{\mathrm{ab}}$ & $243^{\mathrm{a}}$ & $2.67^{\mathrm{b}}$ \\
\hline 135 & $45^{\mathrm{a}}$ & $626^{\mathrm{b}}$ & $248^{\mathrm{b}}$ & $0.92^{\mathrm{b}}$ & $216^{\mathrm{b}}$ & $3.33^{\mathrm{a}}$ \\
\hline
\end{tabular}

${ }^{a}$ Average of two greenhouse experiments each with seven replications.

b Means within a column for each soybean type followed by the same letter are not statistically significant at the 5\% level as determined by Fisher's LSD test.

observed in glufosinate-resistant soybean (Table 6). Likewise, there was a similar change in seed oil composition with a greater abundance of oleic acid and a decrease in linolenic acid. In glyphosate-resistant soybean, the linoleic acid content also decreased after glufosinate application. A similar trend for seed protein, oil, oleic acid, linoleic acid, and linolenic acid was also observed in conventional soybean (Table 6). The results suggest that glufosinate may alter carbon metabolism. It was reported that other herbicides such as glyphosate can alter carbon flow [27], and carbon and nitrogen assimilation [19], leading to protein, oil, and fatty acid changes. The observed inverse relationship between protein and oil has been previously reported $[28,29]$. The increase of seed protein after glufosinate application could be due to a stress response of soybean to the herbicide. For example, it was found that seed protein increased due to environmental stresses such as drought [30], diseases [31, 32], and glyphosate [19]. The increase in oleic acid and decrease in linolenic acids could be due to indirect physiological disturbances that affect fatty acid desaturases, as suggested by Bennett et al. [33], or as a result of carbon metabolism alteration as suggested by Bellaloui et al. [19].

3.2. Greenhouse Experiment. Since the effect of glufosinate on plant biomass and nitrogenase activity was either absent in glufosinate-resistant soybean or inconsistent in glyphosate-resistant and conventional soybean under field conditions, greenhouse studies were conducted using glufosinate at $1 \mathrm{x}$ and $3 \mathrm{x}$ label rate (450 and 1,350 g/ha, resp.) in glufosinate-resistant soybean. Glufosinate at 45 and $135 \mathrm{~g} / \mathrm{ha}$, representing a scenario of 10 and $30 \%$ label rate $(450 \mathrm{~g} / \mathrm{ha})$ was used to simulate drift in conventional and glyphosateresistant soybean. The higher rate was selected to simulate a "worst case scenario" to promote soybean injury. Application of either a $1 \mathrm{x}$ or $3 \mathrm{x}$ rate of glufosinate had no affect on glufosinate-resistant soybean shoot, root, and nodule biomass, nitrogenase activity or root respiration, however nitrogen content of shoot was significantly increased with increasing rates of glufosinate (Table 7). When a 30\% label rate of glufosinate was applied to either glyphosate-resistant or conventional soybean, root and shoot biomass, nitrogenase activity and respiration were significantly decreased compared to nontreated plants (Table 7). As was observed in glufosinate-resistant soybean, shoot nitrogen content significantly increased with increasing rates of glufosinate in glyphosate-resistant and conventional soybean.

These results indicate that glyphosate-resistant and conventional soybean exposed to glufosinate drift may exhibit transient injury (speckling, necrosis, and chlorosis) and can recover from injury over time. Glufosinate had no effect on yield; increased leaf nitrogen at R4 growth stage, seed protein, and oleic acid; decreased oil content, linoleic, and linolenic acid in glufosinate-sensitive soybean. In glufosinate-resistant soybean, chlorophyll content, nitrogenase activity, root respiration, plant biomass, and soybean yield were not affected while seed nitrogen and protein were increased and seed oil content decreased. Altered N accumulation and seed composition in response to glufosinate were observed in all soybean types under field conditions. In a greenhouse study, glufosinate at 30\% decreased root and shoot biomass, nitrogenase activity, and root respiration in glufosinate-sensitive soybean while glufosinate at $3 \mathrm{x}$ rate had no affect on these parameters in glufosinate-resistant soybean. Overall, glyphosate-resistant and conventional soybean can adequately compensate to exposure to a moderate drift of glufosinate without compromising yield.

\section{Acknowledgments}

The authors thank Earl Gordon, Efren Ford, Terry Newton, and Sandra Mosley for field and laboratory technical assistance. Mention of trade names or commercial products in this publication is solely for the purpose of providing 
specific information and does not imply recommendation or endorsement by the U. S. Department of Agriculture.

\section{References}

[1] S. A. Senseman, "Glufosinate," in Herbicide Handbook, S. A. Senseman, Ed., pp. 247-248, Weed Science Society of America, Lawrence, Kan, USA, 2007.

[2] K. N. Reddy, "Impact of rye cover crop and herbicides on weeds, yield, and net return in narrow-row transgenic and conventional soybean (Glycine max)," Weed Technology, vol. 17, no. 1, pp. 28-35, 2003.

[3] K. N. Reddy and D. Chachalis, "Redvine (Brunnichia ovata) and trumpetcreeper (Campsis radicans) management in glufosinate- and glyphosate-resistant soybean," Weed Technology, vol. 18, no. 4, pp. 1058-1064, 2004.

[4] R. L. Ritter and H. Menbere, "Weed management systems utilizing glufosinate-resistant corn (Zea mays) and soybean (Glycine max)," Weed Technology, vol. 15, no. 1, pp. 89-94, 2001.

[5] W. J. Everman, C. R. Mayhew, J. D. Burton, A. C. York, and J. W. Wilcut, "Absorption, translocation, and metabolism of ${ }^{14} \mathrm{C}$-glufosinate in glufosinate-resistant corn, goosegrass (Eleusine indica), large crabgrass (Digitaria sanguinalis), and sicklepod (Senna obtusifolia)," Weed Science, vol. 57, no. 1, pp. $1-5,2009$.

[6] W. J. Everman, W. E. Thomas, J. D. Burton, A. C. York, and J. W. Wilcut, "Absorption, translocation, and metabolism of glufosinate in transgenic and nontransgenic cotton, palmer amaranth (Amaranthus palmeri), and pitted morningglory (Ipomoea lacunosa)," Weed Science, vol. 57, no. 4, pp. 357-361, 2009.

[7] E. W. Logusch, D. M. Walker, J. F. McDonald, and J. E. Franz, "Inhibition of plant glutamine synthetases by substituted phosphinothricins," Plant Physiology, vol. 95, no. 4, pp. 10571062, 1991.

[8] P. J. Lea, K. W. Joy, J. L. Ramos, and M. G. Guerrero, "The action of 2-amino-4-(methylphosphinyl)-butanoic acid (phosphinothricin) and its 2-oxo-derivative on the metabolism of cyanobacteria and higher plants," Phytochemistry, vol. 23, no. 1, pp. 1-6, 1984.

[9] J. M. Green and L. A. Castle, "Transitioning from single to multiple herbicide-resistant crops," in Glyphosate Resistance in Crops and Weeds: History, Development, and Management, V. K. Nandula, Ed., pp. 67-91, John Wiley \& Sons, Hoboken, NJ, USA, 2010.

[10] USDA, United States Department of Agriculture, "National Agricultural Statistics Service," 2010, http://usda.mannlib. cornell.edu/MannUsda/viewDocumentInfo.do?document $\mathrm{ID}=1000$.

[11] I. Heap, "The International Survey of Herbicide Resistant Weeds," 2010, www.weedscience.com .

[12] T. W. Eubank, D. H. Poston, V. K. Nandula, C. H. Koger, D. R. Shaw, and D. B. Reynolds, "Glyphosate-resistant horseweed (Conyza canadensis) control using glyphosate-, paraquat-, and glufosinate-based herbicide programs," Weed Technology, vol. 22, no. 1, pp. 16-21, 2008.

[13] J. M. Ellis and J. L. Griffin, "Soybean (Glycine max) and cotton (Gossypium hirsutum) response to simulated drift of glyphosate and glufosinate," Weed Technology, vol. 16, pp. 580586, 2002.
[14] J. M. Ellis, J. L. Griffin, S. D. Linscombe, and E. P. Webster, "Rice (Oryza sativa) and corn (Zea mays) response to simulated drift of glyphosate and glufosinate," Weed Technology, vol. 17, no. 3, pp. 452-460, 2003.

[15] R. A. Ludwig and E. R. Signer, "Glutamine synthetase and control of nitrogen fixation in Rhizobium," Nature, vol. 267, no. 5608, pp. 245-248, 1977.

[16] N. Bellaloui, K. N. Reddy, R. M. Zablotowicz, and A. Mengistu, "Simulated glyphosate drift influences nitrate assimilation and nitrogen fixation in non-glyphosate-resistant soybean," Journal of Agricultural and Food Chemistry, vol. 54, no. 9, pp. 3357-3364, 2006.

[17] K. N. Reddy, N. Bellaloui, and R. M. Zablotowicz, "Glyphosate effect on shikimate, nitrate reductase activity, yield, and seed composition in corn," Journal of Agricultural and Food Chemistry, vol. 58, no. 6, pp. 3646-3650, 2010.

[18] R. M. Zablotowicz and K. N. Reddy, "Nitrogenase activity, nitrogen content, and yield responses to glyphosate in glyphosate-resistant soybean," Crop Protection, vol. 26, no. 3, pp. 370-376, 2007.

[19] N. Bellaloui, R. M. Zablotowicz, K. N. Reddy, and C. A. Abel, "Nitrogen metabolism and seed composition as influenced by glyphosate application in glyphosate-resistant soybean," Journal of Agricultural and Food Chemistry, vol. 56, no. 8, pp. 2765-2772, 2008.

[20] W. R. Fehr, C. E. Caviness, D. T. Burmood, and J. S. Pennington, "Stage of development descriptions for soybeans, Glycine max (L.) Merrill,” Crop Science, vol. 11, pp. 929-931, 1971.

[21] G. Shearer and D. H. Kohl, " $\mathrm{N}_{2}$-fixation in field settings: estimations based on natural ${ }^{15} \mathrm{~N}$ abundance," Australian Journal of Plant Physiology, vol. 13, no. 6, pp. 699-756, 1986.

[22] J. D. Hiscox and G. F. Israelstam, "A method for the extraction of chlorophyll from leaf tissues without maceration," Canadian Journal of Botany, vol. 57, pp. 332-1334, 1979.

[23] AOAC, "Method 988.05," in Official Methods of Analysis, K. Helrich, Ed., The Association of Official Analytical Chemists, Arlington, Va, USA, 15th edition, 1990.

[24] AOAC, "Method 920.39," in Official Methods of Analysis, K. Helrich, Ed., Arlington, Va, USA, The Association of Official Analytical Chemists, 15th edition, 1990.

[25] E. Boydak, M. Alpaslan, M. Hayta, S. Gerçek, and M. Simsek, "Seed composition of soybeans grown in the Harran region of Turkey as affected by row spacing and irrigation," Journal of Agricultural and Food Chemistry, vol. 50, no. 16, pp. 47184720, 2002.

[26] J. R. Wilcox and R. M. Shibles, "Interrelationships among seed quality attributes in soybean," Crop Science, vol. 41, no. 1, pp. 11-14, 2001.

[27] R. A. Jensen, "The shikimate/arogenate pathway: link between carbohydrate metabolism and secondary metabolism," Physiologia Plantarum, vol. 66, pp. 164-168, 1986.

[28] N. Bellaloui, J. R. Smith, J. D. Ray, and A. M. Gillen, "Effect of maturity on seed composition in the early soybean production system as measured on near-isogenic soybean lines," Crop Science, vol. 49, no. 2, pp. 608-620, 2009.

[29] J. W. Burton, "Breeding soybean for improved protein quantity and quality," in World Soybean Research Conference III: Proceedings, Shibles R., Ed., pp. 361-367, Westview Press, Boulder, Colo, USA, 1985. 
[30] N. Bellaloui and A. Mengistu, "Seed composition is influenced by irrigation regimes and cultivar differences in soybean," Irrigation Science, vol. 26, no. 3, pp. 261-268, 2008.

[31] N. Bellaloui, A. Mengistu, and R. L. Paris, "Soybean seed composition in cultivars differing in resistance to charcoal rot (Macrophomina phaseolina)," Journal of Agricultural Science, vol. 146, no. 6, pp. 667-675, 2008.

[32] H. Q. Xue, R. G. Upchurch, and P. Kwanyuen, "Relationships between oleic and linoleic acid content and seed colonization by Cercospora kikuchii and Diaporthe phaseolorum," Plant Disease, vol. 92, no. 7, pp. 1038-1042, 2008.

[33] J. O. Bennett, O. Yu, L. G. Heatherly, and H. B. Krishnan, "Accumulation of genistein and daidzein, soybean isoflavones implicated in promoting human health, is significantly elevated by irrigation," Journal of Agricultural and Food Chemistry, vol. 52, no. 25, pp. 7574-7579, 2004. 


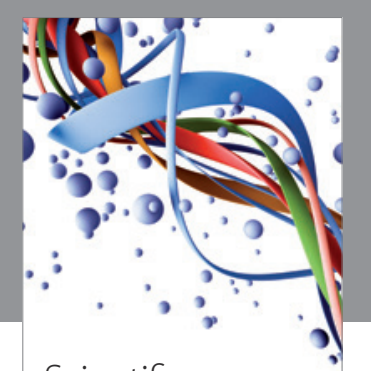

Scientifica
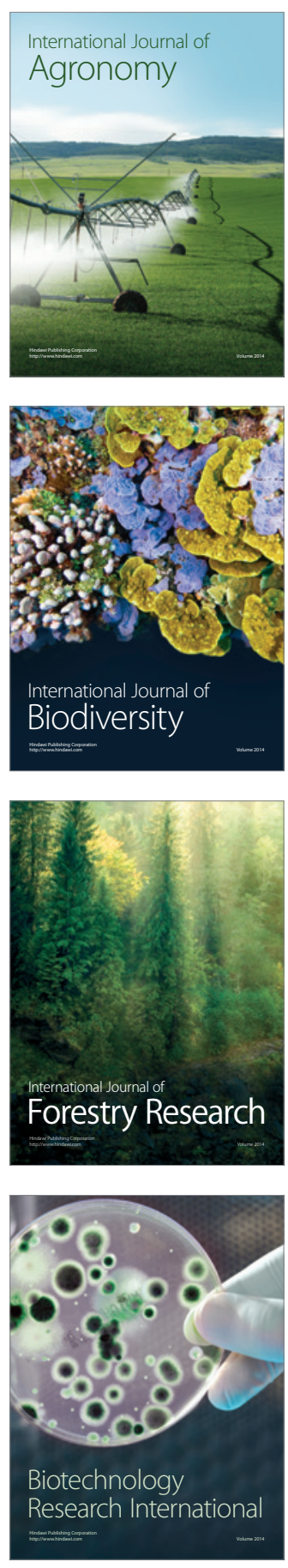
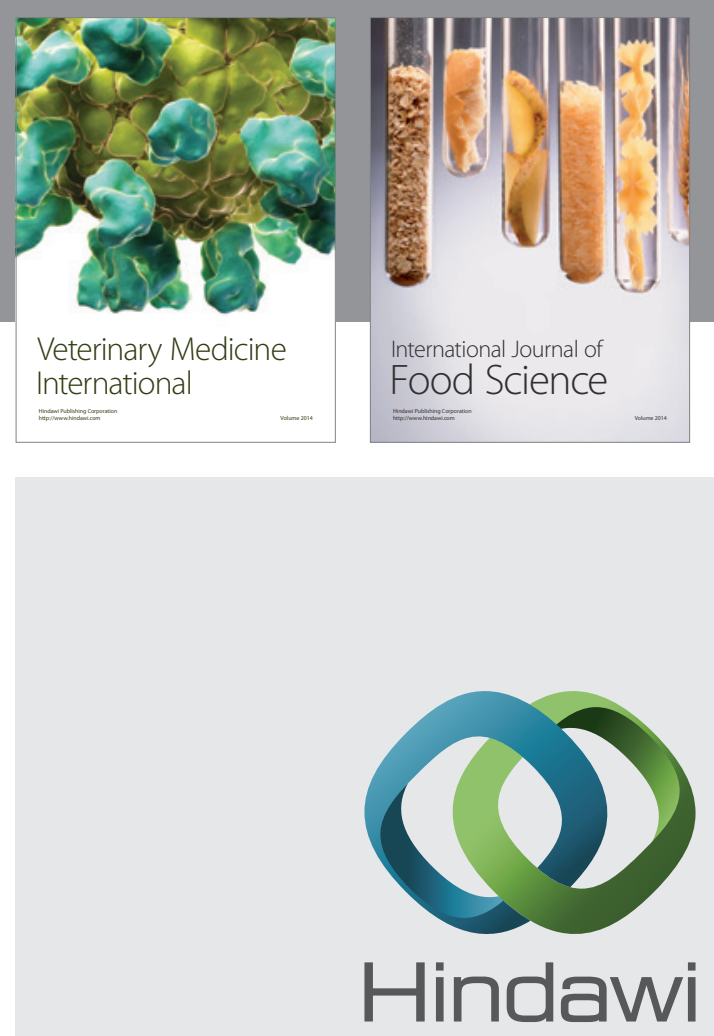

Submit your manuscripts at

http://www.hindawi.com
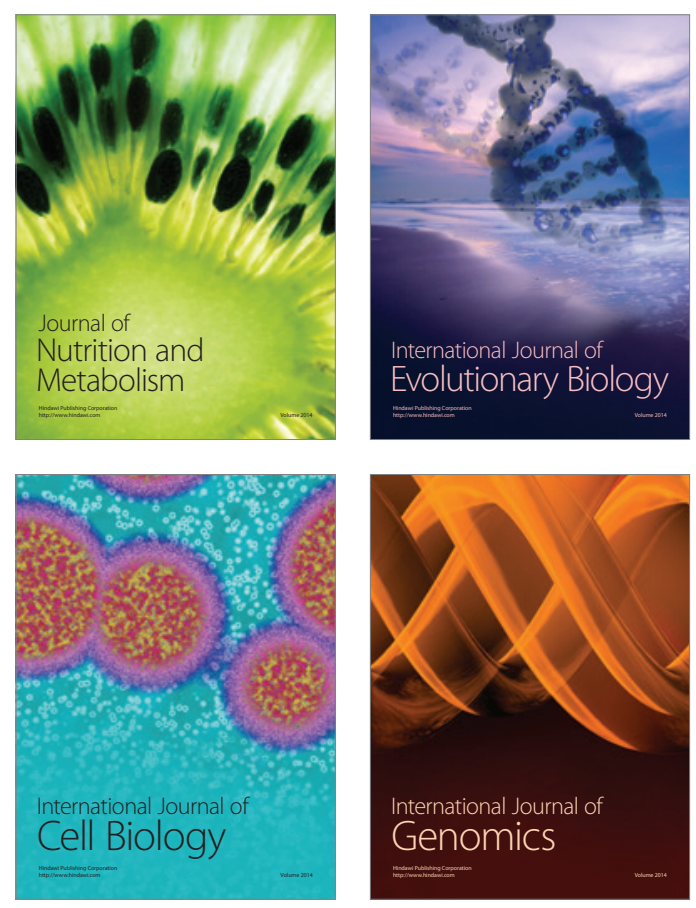
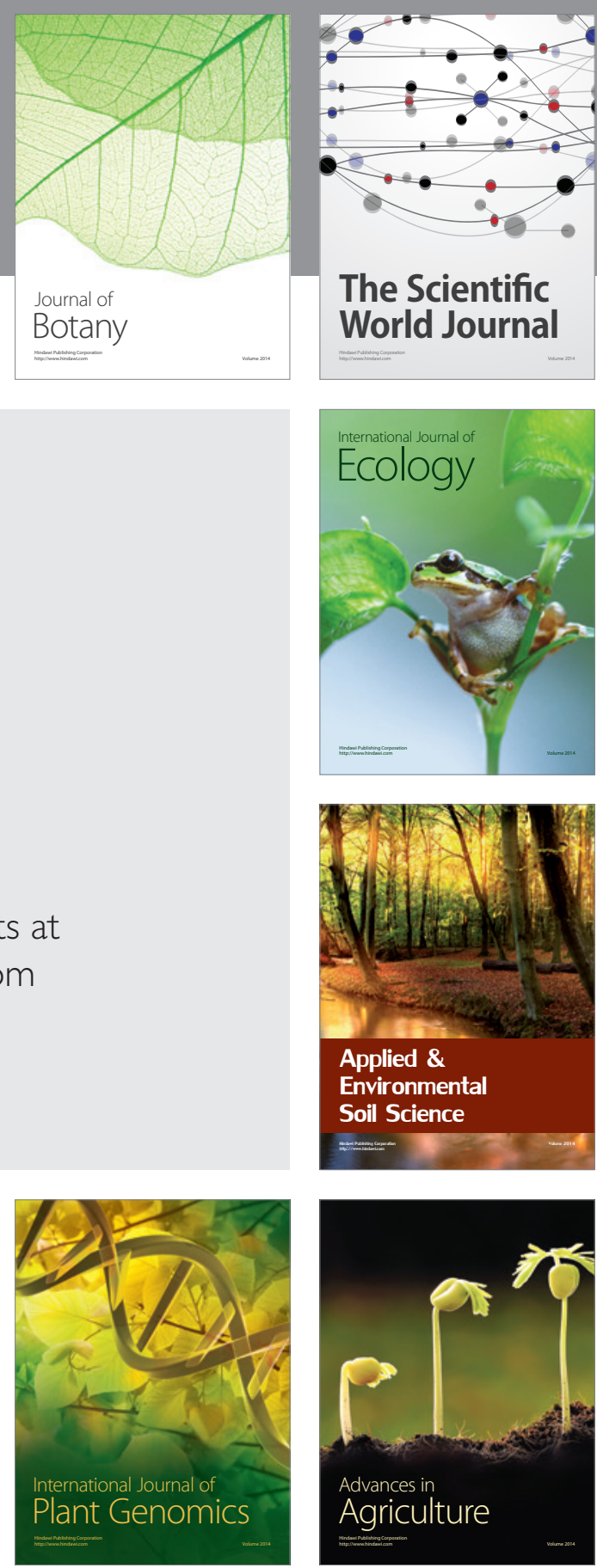

The Scientific World Journal
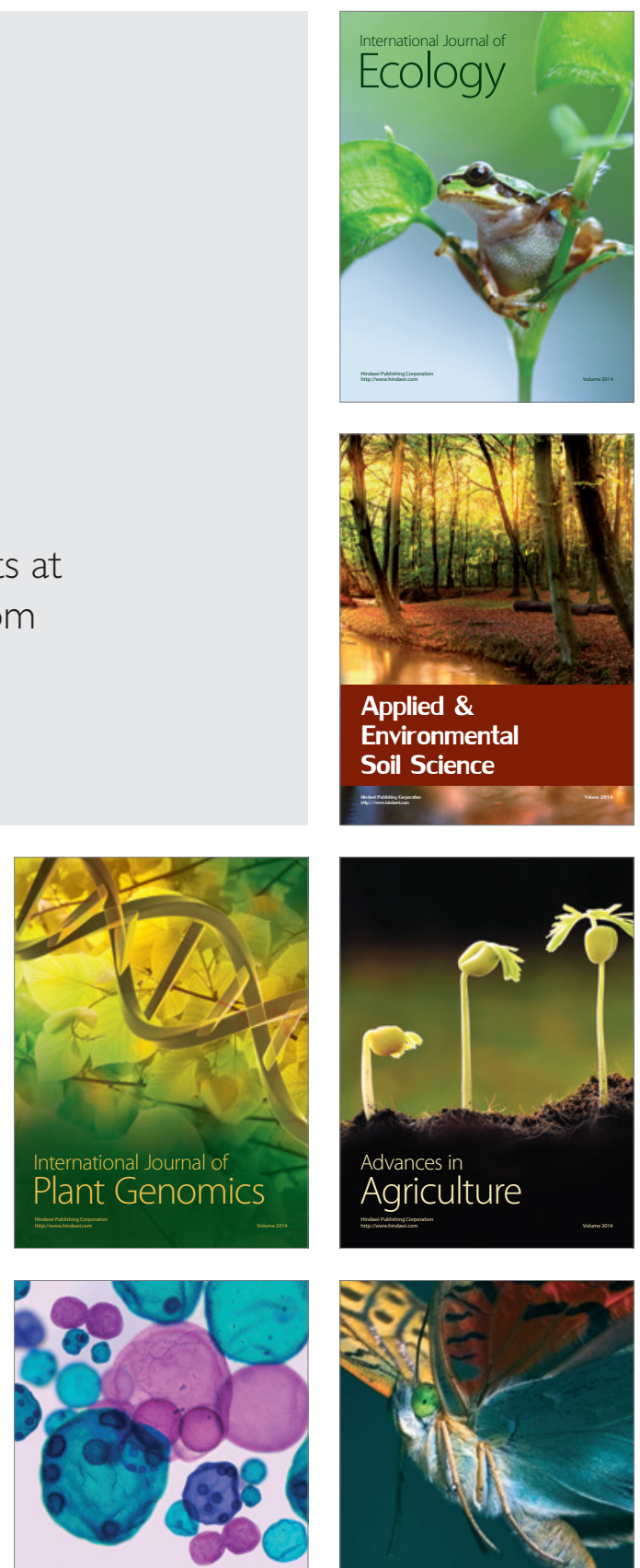

International Journal of Microbiology

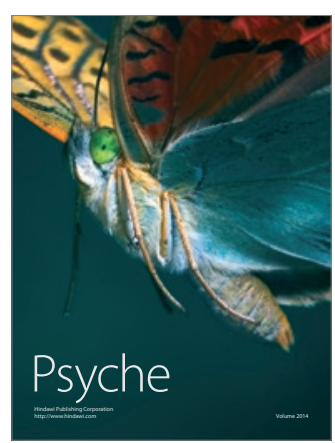

